\title{
O Dever de Solidariedade na Cassação de Mandato de Advogado Constituído
}

\author{
ONodesta Canvalhosa
}

Advogado em São Paulo. Ex-presidente do Tribunal de Ética da OAB-SP

$s$ regras de conduta ética são sucessivas, mas cumulativas, no sentido de que prevalecem tanto aquelas constantes do último Código de Ética editado, como também às das anteriores codificações, na medida em que a regra ética tem como fon te os princípios de conduta que se sedimentam ao longo do tempo. As regras de comportamento profissional não desaparecem dentro de uma mesma cultura, mas se aperfeiçoam. Ademais, a fonte dos princípios ético-profissionais está não apenas nos sucessivos e sempre vigentes códigos, como também nas decisões promanadas pelos Tribunais de Ética que atuam em nossa corporação, como é o caso do TE da OAB SP, fundado em 1936, cujos julgados vêm sendo sistematicamente publicados. E pela universalidade dos princípios éticos no seio de uma mesma civilização também é fonte fundamental da análise da conduta ética os códigos profissionais de outros países, em que ressalta o mais importante e completo de todos eles, o centenário Code of Professional Responsability, da American Bar Association. Esse documento constitui, pela sua contínua atualização, abrangência profundidade, preciosa e indispensável fonte sobre a matéria (in Black's Law Dictionary, $4^{\text {th }}$ Edition, West Publishing, 1968, com as emendas de 1970). A monumentalidade desse histórico Código somente é comparável ao Code of Judicial Conduct, que, as sim, se completam, quanto aos deveres de conduta dos juízes e dos advogados, que formam o cerne da atividade judicial.

Feitas essas observações sobre as fontes das normas éticas, declino a questão apresentada pelo ilustre advogado: "Diante dos artigos 11 e 14 do Código da Advocacia da $O A B$, e em face de conflito entre advogado constituído e seu cliente em torno do valor de honorários, subme. tido a arbitramento judicial, qual a conduta que deve ser seguida pelo novo advogado, que substitui o primeiro?"

A regra que prevalece na questão ora argüida é a constante da letra " $b$ " e "i" da Seção II, item, do Código de Ética anterior: "Deve o advogado: (omissis). h) - não aceitar procuração sem a anuência do advogado com quem tenha de colaborar ou a quem substitua, salvo nesta hipótese, para 
revogação de mandato anterior, por motivo justificado; i) - verificar com isenção, os motivos da resolução do cliente, quando convidado para substituir outro advogado constituído anteriormente, aconselhando, nesse caso, o cliente a obter a desistência do mandato anterior e a liquidar previamente as contas do seu colega".

Cabe convencer-se livremente, portanto, o novo advogado da existência ou não de justa causa para o despedimento. Se convencido de que não há justa causa, deve solidarizar-se com o colega despedido e exercer a função indeclinável de promover a conciliação dos interesses envolvidos; instando o seu novo cliente a liquidar os honorários do primeiro advogado.

Daí se deduz que tem o novo advogado constituído uma função conciliadora, o que não impede, quando houver motivo justo para despedir, de aceitar, desde logo, o mandato substitutivo.

Nesse sentido, se interpreta o art. 11 do Código de Ética: "O advogado não deve aceitar procuração de quem já tenha patrono constituído, sem prévio conhecimento deste, salvo por motivo justo, ou para adoção de medidas judiciais urgentes e inadiáveis".

O pressuposto, portanto, para a aceitação ou não, é o motivo justo ou injustificado. $\mathrm{O}$ novo advogado aceita, desde logo, o mandato se está convencido, diante da natureza do conflito instalado entre o seu colega e o cliente, do motivo justo da despedida. Se assim não fosse, ou seja, se não se conduzisse o novo advogado com a isenção referida na norma ética, entre os interesses conflitantes surgidos $d$ relação profissional anterior, estaria ele criando uma situação de verdadeira extorsão a favor de seu colega.

Num verdadeiro pactum sceleris, nenhum advogado aceitaria o novo mandato, enquanto não fossem pagos os honorários demandados pelo antigo, por mais imoderados ou indevidos que fossem. Além da extorsão, ocorreria o desamparo do direito subjetivo deste, na medida em que os advogados têm o monopólio de pleitear em juízo os interesses das partes. Daí a ressalva contida nos preceitos éticos acima transcritos, ou seja, da isenção e neutralidade do novo advogado na formação do seu livre convencimento sobre a existência ou não da justa causa.

Nesse sentido, a paradigmática decisão do E. TE-OAB-SP, no E-910, relator o preclaro jurista Dr. Elias Farah, que sempre honrou, com sua inestimável contribuição, aquele sodalício. Ementa: "Revogação de Mandato. Substituição de patrono. Obrigações éticas do substituto. Conveniência da observância, quanto possível, sem prejuízo do patrocínio, do disposto no art. 87 , XIV, do Estatuto e da Seção II, item I, letras 'H' e 'I' do Código de Ética Profissional. Tais disposições se inspiram no dever de solidariedade profissional e corporativa e no resguardo dos interesses econômicos do colega, quanto a honorários advocatícios. Necessidade de adequação das exigências a cada caso específico. Dispensa assegurada de tais cautelas quando no atendimento de medidas judiciais urgentes ou inadiáveis, cuja inexecução possa apresentar danos irreparáveis. Todavia, para o prosseguimento do patrocínio, deve o consulente cumprir o disposto na letra ' $h$ ' da Seção I do CEP e parte final do art. 87, XIV, letra ' $b$ ' (in julgados do Tribunal de Ética Profissional, OAB-SP, org. Dr. Robison Baroni, vol. II, Departamento Editorial da OAB-SP, págs. 281 e segs.).

E, com efeito, os preceitos éticos supracitados visam a proteger os advogados contra a despedida por motivo injusto, geralmente relacionada com a tentativa do cliente de escamotear honorários devidos e contratados, no momento em que ocorre a solução favorável da sua pretensão.

Assim, para exemplificar com os casos mais comuns: o advogado é contratado para obter a justa indenização devida em processo de desapropriação. Para tanto, contrata honorários com o cliente. Ocorre que, na fase de levantamento ou precatório, do valor arbitrado, e uma vez reconhecido, portanto, judicialmente o valor recebível, o cliente promove a destituição do advogado constituído, para o fim de elidir, no curso da execução do seu crédito, o pagamento dos honorários avençados. Esse ato ilícito é tão usual que o Estatuto da Advocacia prevê remédio. Assim, o $§ 4^{\circ}$ do art. 22: "Se o advogado fizer juntar aos autos o seu contrato de honorários antes de expedir-se o mandado de levantamento ou precatório, o juiz deve determinar que lhe sejam pagos diretamente, por dedução da quantia a ser recebida pelo constituinte, salvo se este provar que já os pagou".

Trata-se, no caso exemplificado, de motivo injusto de despedimento. Não deve, nesse caso, um novo advogado acei- tar o mandato sem antes manifestar, inequivocadamente, sua solidariedade, promovendo todas as instâncias para que o primeiro receba a sua honorária. Há um impedimento moral irrecusável, no caso. $\mathrm{O}$ advogado que, desde logo, aceitar o mandato nesse caso estará cometendo grave dano à classe, na medida em que acoberta ato ilícito do cliente, qual seja, a de elidir o pagamento dos honorários devidos ao antigo advogado, mediante a nomeação de um outro. Não pode o causídico prestar-se a esse papel indigno, que levará ao enrique. cimento ilícito do cliente.

Isto posto, cabe aqui trazer o art. 14 do Código de Ética Profissional: "A revogação do mandato judicial por vontade do cliente não o desobriga do pagamento das verbas honorárias contratadas, bem como não retira o direito do advogado de receber o quanto lhe seja devido em eventual verba honorária de sucumbência, calculada proporcionalmente, em face do serviço efetivamente prestado".

Esse preceito institui o princípio da moderação e proporcionalidade dos honorários contratados, tendo como critério os serviços efetivamente prestados.

O princípio da moderação está inscrito na Exposição de Motivos do Código de Ética da OAB: "A palavra honorários tem a sua raiz na palavra honra, o mesmo que honor. Como substantivo masculino plural, quer dizer: remuneração pecuniária de serviços prestados por aqueles que exercem profissão liberal, estipêndio; paga, retribuição. Os honorários advocatícios são a retribuição devida a quem presta uma atividade intelectual indispensável à àdmi- 
nistração da justiça e não devem ser considerados como preço, este ligado à ativi dade comercial e à mercantilização".

Desse cânone infere-se que imoderação dos honorários contratados constitui justa causa de despedida do advogado, por parte do seu cliente. É, com efeito, incompatível com a atividade pro fissional o desidério de enriquecimento à custa do patrimônio do cliente. $\mathrm{O}$ advogado não pode enriquecer contratando honorários incompatíveis com a prestação profissional de seus serviços. A regra é tanto mais aplicável quando estão envolvidos grandes interesses patrimoniais.

Não pode o advogado comportar-se como sócio do seu cliente nos negócios que este realiza com a sua intervenção profissional ou nas questões judiciais que patrocina.

Assim sendo, o advogado sucessor deve, com isenção e livre convencimento, ponderar sobre a relação e proporção entre os serviços efetivamente prestados e os honorários cobrados pelo seu antecessor Para tanto, vale-se dos critérios universal mente aceitos, como se pode ver, do referido Code of Professional Responsability da American Bar Association, que, no seu Segundo Cânone - Fees of Legal Services -, regra DR-2, letra "a", estabelece que "o advogado não deve celebrar contrato de honorários visando a cobrar ou a obter honorários excessivos ou ilegais. E a letra " $b$ " define a imoderação da seguinte forma: "Os honorários serâo considerados inquestionavelmente excessivos quando, após uma análise dos fatos, um advogado prudente consideraria que os mesmos fogem dos padrões de moderação".
E prossegue a referida regra do célebre Cânone Segundo do Código da ABA, apontando os fatores que devem ser considerados como critérios de determinação da razoabilidade ou não dos honorários: "O tempo e o trabalho requeridos; a excepcionalidade e a dificuldade das questões envolvidas; a habilidade exigida para a execução adequada dos serviços profissionais; os honorários costumeiramente cobrados na localidade onde o advogado atua, por serviços profissionais similares; o valor envolvido e os resultados obtidos; o tempo de dedicação exigido pelo cliente ou pelas circunstâncias do caso; a natureza e a extensão das relações profissionais do advogado com o seu cliente; a experiência, reputação e habilidade do advogado encarregado de tais serviços profissionais; se os honorários são convencionados pelo critério fixo ou de sucesso".

Temos assim a regra universal que, convencido da imoderação, não se obriga o novo advogado constituído a prestar solidariedade ao antigo colega. A este cabe reivindicar seus honorários em juízo, que constitui o foro próprio para arbitrá-los.

É no foro judicial, com efeito, que o advogado despedido encontra a proteção de seu direitos. Esse é o caminho que deve palmilhar. Havendo conflito sobre honorários que o cliente julga imoderados, deve o advogado cassado alegar a justeza do seu valor, submetendo-se ao arbitramento judicial. Nesse sentido, dispõe expressamente o Estatuto da Advocacia em seus artigos 22 e 24. Assim, o art. 22, caput: "A prestação de serviço profissional assegura aos inscritos na $\mathrm{OAB}$ o direito aos honorários convencionados, aos fixados por arbitramento judicial e aos de sucumbência".

E o $§ 2^{\circ}$ desse mesmo artigo 22 do Estatuto prescreve a regra fundamental da moderação dos honorários: " $\mathrm{Na}$ falta de estipulação ou de acordo, os honorários são fixados por arbitramento judicial, em remuneração compatível com o trabalho $e$ o valor econômico da questão, não podendo ser inferiores aos estabelecidos na tabela organizada pelo Conselho Seccional da OAB". E, também, o artigo 24: "A decisão judicial que fixar ou arbitrar honorários e o contrato escrito que o estipular são títulos executivos e constituem crédito privilegiados na falência, concordata, concurso de credores, insolvência civil e liqui dação extrajudicial".

Reitera-se, portanto, que deixa de existir - mesmo porque não será de nenhuma utilidade - a função de convencimento do novo advogado junto ao seu cliente quando o antigo advogado ingressa em juízo para a cobrança dos honorários que julga devidos. Desaparece aí o dever ético de solidarizar-se, desaparecendo mesmo a razão prática de sua convicção pessoal sobre a eventual justiça dos honorários pretendidos, já que passa a repousar no juiz o deslinde da questão honorária conflituosa que levou à dispensa.

A propósito, a paradigmática decisão da TE da OAB-SP, $\mathrm{n}$ 으. 1.175 , relator ilustre Dr. Antônio Lopes Muniz, de cuja ementa consta: "Tendo o consulente por justificados os motivos da revogação, poderá receber procuração e ingressar aos au tos judiciais, firmando contrato escrito de honorários" (in Julgados, vol. III, págs. 301 e segs.).
Essa regra de livre convencimento do advogado substituto sobre as razões da despedida é reiterado pelo TE da OAB-SP, in julgado E. 1.204, relator o ilustre e saudoso, decano, Dr. Milton Basaglia, cuja ementa é esclarecedora sobre o caráter subjetivo $\mathrm{e}$ não compulsório da intervenção do novo advogado na pendência entre o cliente $\mathrm{e}$ seu colega: "O cliente é o juiz único para outorgar e cassar procuração de advogado que constituiu. Diante da prova da cassação, outro advogado poderá ser constituído e receber o procuratório, sendo aconselhável sopesar os fundamentos da revogação anterior, não só por deferência ao colega, cassado, com também se não será futura vítima de igual atitude. Quando, entretanto, convidado para substituir outra colega em exercício, deve igualmente verificar os motivos, com isenção e, nesta segunda hipótese, deve antes aconselhá-lo a obter renúncia ou substabelecimento do advogado titular do mandato existente. Aconselhando-o, também, a liquidar previamente as contas com o seu colega" (Código de Ética Profissional, Seção II, Inciso I, alínea "i", in ob. cit. vol. III, págs. 350 e segs.).

E o justo motivo, como razão sub. jetiva suficiente para o recebimento de novo mandato sem o oferecimento de solidariedade é reiterado pelo TE da OAB-SP, conforme se pode verificar do decisório daquela Corte corporativa, julgado E. 1.294, de 21.09.1995, relator o emérito advogado Dr. Bruno Sammarco. Ementa: "Recebimento por advogado de procuração de quem já tenha patrono constituído nos autos. Impossibilidade sem prévio conhecimento deste, salvo por motivo justo ou para adoção de medidas judiciais urgentes e inadiáveis". 
Ademais, quando o advogado substituto encontra uma situação definida de litígio judicial entre o advogado anterior $\mathrm{e}$ o seu antigo cliente, o que poderia fazer? Exigir a confissão da ação pelo seu clienteréu, ou que este se submetesse a uma transação judicial, para que, somente após, viesse a assisti-lo? Ambas as exigências seriam antiéticas por parte do substituto, na medida em que existe, como referido, a favor dos advogados, o monopólio de intervir em juízo.

Seria forma de constrangimento e mesmo de coação, ainda que não a favor dele próprio advogado substituto, mas a favor do colega cassado. Este poderia, assim, auto-arbitrar-se do valor dos seus honorários, sem que pudesse o seu cliente continuar socorrendo-se do suprimento judicial, por boicote dos advogados convidados a substituir o primeiro.

Dessa forma, o ingresso em juízo, por parte do advogado anterior, para cobrança de honorários, dispensa a intervenção do advogado substituto, que não tem qualquer função ética na pendência, já que assegurado o direito dos litigantes, através da decisão judicial.

E não tendo qualquer função de natureza ética a favor de seu colega nesse caso, por outro lado, não pode o advogado solicitado a substitui-lo deixar de receber desde logo o mandato, sob pena de não cumprir o seu papel de auxiliar indispensável da justiça, no patrocínio indispensável dos interesses de seu constituinte.

Reitere-se este aspecto. $O$ dever ético é de o novo advogado procurar conciliar os interesses de seu novo cliente com aqueles do seu colega, em termos de honorários, quando convencido da inexistência de justa causa para a despedida. Se, no entanto, a lide está instalada, não poderá mais exercer essa função conciliatória, mesmo se convencido da falta de justa causa. $\mathrm{E}$, se convencido da justa causa, inclusive pela eventual imoderação dos honorários requeridos, essa função jamais se impõe eticamente, conforme se deduz do citado texto, da Seção II, inciso I, letra " $h$ " e Seção VIII, inciso I, do Código de Ética.

Será, com efeito, irrepreensível a conduta ética de abstenção de solidariedade do novo advogado quando o conflito entre o constituinte e o advogado anterior for de tal gravidade que induza ao convencimento da justa causa. Nesse sentido, a decisão do TE da OAB-SP, E. 1.298, relator o ilustre Dr. Júlio Cardella, in 14.12.1995, cuja ementa é a seguinte: "O mandato judicial é revogável a qualquer momento pelo mandante, que é o único juiz de seus interesses. (...) Os mandatos judiciais não podem conter cláusula de irrevogabilidade por contrariar o dever de o advogado renunciar a eles caso sinta faltar a confiança do mandante, o que fica patente com a manifestação da vontade de revogar. Tendo ocorrido revogação do mandato outorgado ao advogado anteriormente constituído, é lícito à consulente receber procuração desse cliente" (in ob. cit. vol. IV, págs. 254 e segs.).

Concluímos, assim, que o princípio moderação de cobrança da verba honorária é pressuposto para o que novo advogado promova, como conciliador, a aproximação entre o seu novo cliente e o colega despedido, para que atenda ao pedido da verba honorária. Não cabe ao novo advogado, sob qualquer pretexto, promover essa aproximação, para o recebimento de honorários que ele próprio - novo advogado - ache imoderado para si próprio, seja pelo montante requisitado, seja pela desproporcionalidade face aos serviços prestados. Prevalece, aqui a figura do advogado prudente, a que se refere o Code of Professional Responsability, da ABA. Isto posto, poderá e, mais do que isso, deverá o novo advogado assumir a defesa dos interesses do seu cliente, independentemente de qualquer conduta de solidariedade e do exercício do papel de conciliador

Isto posto, concluímos que o dever de solidariedade do novo advogado constituído, para com o seu colega despedido, condiciona-se à existência ou não de justa causa para a despedida. Se convencido da justa causa, não se impõe a solidariedade. E se a questão do despedimento se desenvolve em torno da moderação ou não dos honorários contratados com o antigo advogado, o seu livre convencimento sobre o dever de solidariedade repousa nos critérios geralmente aceitos de proporcionalidade e moderação, pelo advogado prudente. Convencendo-se da imoderação, o novo advogado não tem dever de solidariedade.

$E$, finalmente, estando a questão honorária submetida a arbitramento judicial, o eventual dever de solidariedade é inaplicável, porque ineficaz e, assim, de nenhuma utilidade, já que a matéria desloca-se para o nível de convencimento e de arbitramento do juízo. 